most powerful hømostatics, such as the percbloride of iron, are of any avail. It is in the nature of such cases to proceed to septicømia - a circumstance entirely overlooked when the iron is blamed with this unfortunate result, with which it appears to me to have nothing to do.

As far as I can judge, from intercourse with my professional brethren, confidence in the use of perchloride of iron, as a bæmostatic, is steadily on the increase, and the dread of ill consequences fast disappearing; and I shall be very glad if the case now related will in any way help to settle an impostant point in obstetric practice.

I am, Sir, your obedient servant,

Liverpool, Sept. 4th, 1877. Gro. Shearer, M.D.

\section{DR. BURDON-SANDERSON'S CHANGED VIEW REGARDING THE ULTIMATE NATURE OF CONTAGION. \\ To the Editor of The Lancert.}

SIR,-We have this week received a copy of the last Report of the Medical Officer of the Privy Council (1876), and observe that Dr. Burdon-Sanderson has now come to the conclusion, regarding the active principle in virulent eptic liquids, that "it can scarcely be supposed that the agent is a living organism" (page 14). Will you permit us to give in your columns the last paragraph of our summary of a series of experiments of an allied character, published in the Tenth Annual Report of the Sanitary Commissioner with the Government of India (1874)? - "Therefore, until it be proved that living substances can withstand immersion in a fluid at a temperature of $212^{\circ} \mathrm{F}$. of some minutes' duration, we have no hesitation in stating that the morbid phenomena which we have observed to follow the introduction into the animal economy of strained solutions of choleraic and normal alvine discharges, and of other decomposing animal substances, are not the result of infection with a material the poisonous properties of which are dependent on its possessing vitality."

This conclusion was based on observations made on 170 dogs. Dr. Sanderson's is based on observations on 25. We understand that the Reports detailing these experiments were forwarded as issued to Dr. Burdon-Sanderson, but they appear to have escaped his notice. It is, however, satisfactory to find that so eminent an exponent of doctrines regarding the causation of disease has now arrived at similar conclusions, and that he has, on the present occasion, sabmitted views for the guidance of the public health officers at home so much in accordance with those previously arrived at by the sister department in India.

We quite agree "that it would have been better for pathological science if such conclusions had not been so much overlooked, for the facts on which they are based are quite irreconcilable with the of ten too carelessly received assumption that the process of septic infection is dependent on the development of a living contagium "(page 13); though, in common with all who have studied Dr. Burdon-Sanderson's writings during the last ten years, we are astonished to find him the preacher of such doctrine. We are, Sir, yours obediently,

Calcutta, July 25 th, 1877.

D. D. Cunningham,

\section{THE UNIVERSITY OF LONDON AND MEDICAL WOMEN}

To the Editor of The LANCET.

SIR, - I observe in your leading article in The LaNCET of $J$ uly 14th, that you comment upon the positions which Sir William Gull and Sir James Paget have assumed in the discussion which has lately taken place in regard to the admission of women to degrees in medicine in the University of London. I may be pardoned, I hope, in stating my opinion of Sir James Paget's policy. If he has yielded to the despotism of a majority, why does he not lodge a protest and insist upon its being recorded? I do not agree with you in your condemnation of Sir William Gull's suggestion, that women should be examined on all subjects. As they should be taught in all subjects so should they be examined in the same. Why not? It is as monstrous as it is foolish to suppose that these women in their future routine practice will not have to treat diseases begotten of immorality in their own sex. If women choose, of their own and their responsible advisers' deliberate action, to practise our profession, why should they not be equally prepared to grapple with the "arcana" as with the other ailments to which our flesh is heir? Sir Jas. Paget and those who agree with him will inaugurate a vicious policy, if they launch into the professional world those who have not by the test of public examination been declared and guaranteed to possess a sufficient knowledge in all branches of medical and surgical practice. May not women assist ais much hereafter in stamping out a disease, which, as Providence has so dispensated, may descend to the third and fourth generation? May they not have greater influence for good among their own sex than we have? It is to be hoped that the Senate will not listen to any mischievous half-measure policy, and it will be a source of sincere gratification to many practitioners in this country to learn that the innovation of women doctors will convey the full im. pression that, in scattered populations, they may be qualified to practise their profession as becomes every general practitioner. I had hoped to see the crusade against specialism stern, uncompromising, and exclusive. Make one exception and you will have many.

I nay be pardoned for raising my voice against a halfmeasure policy which, I trust, will be properly settled long before I see this short note in print. I enclose my card.

$$
\text { Yours faithfully, }
$$

Simla, India, Aug. 8th, 1877. SURGEON-MAJOR.

P.S. You will observe that $I$ have not entered into the question of the propriety of admitting women into the ranks of our profession. This would now be useless and unproductive of any good.

\section{ROUMANIAN WAR VICTIMS}

\section{To the Editor of THE LANCET.}

Srr,-In answer to a letter which you were good enough to publish for me some time ago when in England, small sums of money were sent me by different sympathising friends. Lord Aberdour was my largest contributor, two shillings in postage-stamps from a "Poor Servant" being the smallest, but not least appreciated, gift. Now that there are 25,000 Roumanian soldiers on the other side of the Danube, we shall soon need all our hospitals, all our resources, and these latter, in a monetary point of view, will, I fear, be speedily exhausted. The press has spoken of the completeness of the Roumanian Red Cross ambulance. An energetic lady has succeeded in establishing two hospitals on the banks of the Danube. Everyone has given in money or in kind. The Jewish community has been very generous. We have had lotteries, concerts, \&c., to establish these charities, but the grave question presents itself, how are they to be supported? The Roumanian nobility are not wealthy; there is no export now by sea or river ; colonial produce has much increased in price owing to the cost of land transport; there is an absolute dearth of money. At the suggestion of our good Princess, his Eminence the Metropolitan has sanctioned the training of nuns, from some of the convents, as nurses; we have a sufficient number of capable young native doctors, and all are doing what they can.

I had lately the pleasure of going over a cottage hospital formed by our gracious Princess, and furnished from her private purse. Perfect in all its simple details, and close to the summer palace, it will have the personal superintendence of her Highness. It forms the first of what will, I hope, be a series of " the Princess Elizabeth cottage hospitals and asylums." A similar building to the one erected by the Princess has been given by a Jewish gentleman. The money which was confided to me when in England is now being employed to furnish this building, and so the second cottage hospital will be complete. Money may be sent to $m e$ direct, or to the National and Provincial Bank of England, 53, Baker-street; or to R. H. Milson, Esq., 88, Finchley-road, N.W. It will be placed at once into the hands of her Highness, and it is requested that it may be 